\title{
STRAATSBURG EN ARTIKEL 2 VAN DIE DORDTSE KERKORDE
}

In art. 2 K.O. word daar vier soorte kerklike dienste on derskei, nl. „dié van die bedienaars van die Woord, dié van die professore aan die teologiese skool, dié van die ouderlinge, en dié van die diakens".

Hierdie onderskeiding van die vier kerklike dienste word gewoonlik teruggevoer na Calvyn. Inderdaad maak Calvyn by Ef. 4 : 11 'n onderskeid tussen die herders en die leraars en wil dit nie, soos sommige skrifverklaarders, as een amp (unum officium) sien nie. Hy vind ook in die „leraars" (didaskaloi) van die eerste Korinthiërbrief die amp van die doktore terug. Maar dis opmerklik dat Calvyn, ofskoon 'n uitnemende eksegeet, op hierdie punt oor die algemeen geen steun by die nuwere skrifverklaarders vind nie. Mens voel op die punt inderdaad iets van 'n Gereformeerde eksegese.

Die vraag is nou: is hierdie opvatting van die vier kerklike dienste en die skriftuurlike fundering daarvan die oorspronklike konsepsie van Calvyn en, indien wel, kan ons die organiese ontwikkeling van hierdie konsepsie in sy werke naspeur?

Wat die eerste deel van die vraag betref, moet opgemerk word dat dit inderdaad lyk of Calvyn hier 'n oorspronklike visie op die kerkregering hel. In die uitgawe van die Institusie van 1543 is 'n baie omvangryke hoofstuk waarin die skrifbewys vir die vier ampte uitvoerig behandel word. Hier is die basis, so word dikwels aanvaar, van die tipies Calvinisties-Gereformeerde orde vir die kerklike lewe soos dit uitgedruk word in art. 2 van die Kerkorde. ${ }^{1}$ )

Om te bepaal of hierdie opvatting van Calvyn werklik oorspronklik was, is dit nodig om sy vroeëre werke te beskou ten einde vas te stel of dié gedagtes dáár reeds hetsy in verkorte vorm hetsy in embrionale gestalte aanwesig is. Die eerste wat dan in aanmerking kom is die Kerklike Verordening (Ordinances Ecclésiastiques) van 1541, wat Calvyn onmiddellik na sy terugkeer in Genève aan die Raad voorgelê het vir goedkeuring. Daarin vind ons die hele saak duidelik en ondubbelsinnig gestel:

"There are four orders of offices that our Lord instituted for the government of his Church: first the pastors, then the teachers, after them the elders, and fourthly the deacons. 
Therefore if we would have the Church well ordered and maintain it in its entirety, we must observe that form of rule". ${ }^{2}$ )

Hier breek die lyn wat ons teruggevoer het egter af. In sy vroeëre werke vind ons niks van die vier ampte nie. In die eerste uitgawe van die Institusie (1536) word net van die herders en die diakens gepraat. Die benaming ,ouderling" kom hier nie voor nie hoewel hy spreek van persone wat saam met die herder toesig moet hou. Geen spoor egter van vier kerklike ampte nie. Dieselfde geld van die Kerkorde wat Calvyn en Farel aan die Raad van Genève in Januarie 1537 voorgelê het. Hierin word net gepraat van die herders.

Die gemeenskaplike in die Articles van 1537 en die Ordinances van 1541 was die veronderstelling en die poging tot verkryging van 'n kerklike jurisdiksie oor die lidmate, m.a.w. die reg van die kerklike tug. Dit was egter nie iets nuuts nie. In Swabe (sedert 1531), in Basel, in Konstanz - oral was die kerklike tug 'n brandende vraagstuk. Klokslag is poginge gewaag om dit te verwerklik. Luther self het die tug as wesenlike kenmerk van die kerk beskou.

Afgesien van die gemeenskaplike veronderstelling van die kerklike tug, is daar tog 'n kloof tussen die kerkorde van 1537 en dié van 1541: in lg. die leer van die vier ampte, in eg. geen spoor daarvan nie. Bowendien is die uitvoerige hoofstuk oor die skrifbewys vir die vier ampte in die Institusie van 1543 ook 'n byna geheel nuut ingevoegde hoofstuk. Dieselfde kloof lê dus tussen die uitgawe van die Institusie van 1536 (en die Franse vertaling van 1539) en dié van 1543.

Uit hierdie feite kom twee interessante gegewens na vore. Ten eerste, dat Calvyn eers die praktiese reëling van die vier ampte ingestel het (1541) en daarná die teoretiese fundering daarvan gegee het (Institusie 1543). Dit is egter duidelik dat hy reeds hierdie teoretiese insig moes gehad het by die opstel van die kerkorde van 1541. Ten tweede, die kloof tussen 1537 en 1541 toon dat daar in hierdie jare 'n belangrike wysi. ging in die insig van Calvyn plaasgevind het.

Die stad Straatsburg kom hier vanselfsprekend in die gesigsveld. Want dit was presies in hierdie jare (1538-41) dat Calvyn as banneling in Straatsburg verkeer het. Hierdie stad het reeds in 1524 oorgegaan na die Reformasie, en die krag van die reformatoriese aksie is beliggaam in die groot Elsasser, Martin Bucer. Sedert die finale afskaffing van die mis in 1529, 
was die Roomse nie meer die primêre gevaar nie, maar wel die Wederdopers, wat byna chaos in die stad veroorsaak het. Om hierdie gevaar te bekamp, het Bucer twee middele ter hand geneem: aandrang by die stadsowerheid om maatreëls teen die sektariërs te neem en die organisering van die kerk tot 'n hegte organisme wat deur eie ampte toesighoudend en beskermend na binne optree. Kragtig het hierdie Bybelse eksegeet en begaafde organiseerder die kerk verkondig en probeer vergestalt as lewende organisme, as gemeenskap van die heiliges, wat in liefde en diens onderling verbonde is. Waar gemeenskap is, daar is ook tug. Bucer sê dit onomwonde: „Wo keine Zucht und Bann, da ist auch keine Gemeinde".

In sy kerkorde van 1534 word die amp van die ouderling die eerste keer in die reformasietyd helder na vore gebring. "Gott ist ein Gott der Ordnung. Derhalben S. Paulus allenthalben den Kirchen Eltesten verordnet hat und zu verordnen befohlen. Dies ist Gottes Ordnung und Befehl..."

Die belangrikste geskrif van Bucer vir ons onderuerp, is sv "Von der Wahren Seelsorge und dem rechten Hirtendienst" (1538). Hierin word die kerklike ampte met skrifbewys en al uitvoerig behandel. Die dienaars van die Woord en ouderlinge is belas met die regering van die kerk en met die uitoefening van die tug. Hulle word albei herders, leraars, opsieners genoem omdat albei met sielsorg besig is en 'n herderlike amp beklee. Naas hulle staan die diakens. Hoogs belangrik is die skrifbewys van Bucer: hy lê die nadruk op die opsomming van die ampte in Efesiërs en 1 Korinthe. Hy maak die onderskeiding tussen buitengewone en gewone ampte. Onder lg. tel die bedienaars van die Woord, ouderlinge en diakens. In die volgende jaar (1539) plaas Bucer nog 'n vierde amp by: die leraars! Dan stel hy die kerklike ampte naas mekaar: ministerium muneris pastoralis (d.i. die dienaars van die Woord en ouderlinge), procurationes pauperum (diakens) et scholae adolescentium (leraars, doktore).

Dít is die stad Straatsburg wat Calvyn in 1538 binnetree Franse vlugtelinggemeente diens te doen. Hier het hy in die Franse vlugtelinggemeente diens te dien. Hier het hy in die nouste kontak met Bucer en die ander reformatore die $3 \frac{1}{2}$ jaar lank geleef en gewerk. Dit verklaar die kloof in sy siening oor die amp tussen sy kerklike verordeninge van 1537 en van 1541. Wat by Bucer weens teenstand van die stadsowerheid 
hoofsaaklik teorie gebly het, kon Calvyn na sy terugkeer in Genève in die praktyk verwesenlik.

Ons moet dus art. 2 K.O. na Straatsburg terugvoer! Hiertoe is die invloed van Straatsburg (en veral van Bucer) op Calvyn geensins beperk nie. Nog een interessante voorbeeld: geïnspireer deur die gemeentesang van die kerke in Straatsburg, veral onder leiding van die energieke musikus Matthias Greiter, gee Calvyn in hierdie jare sy eerste bundeltjie met Franse psalms uit - die begin van die volledige psalmbundel van 1559 wat Nederland en ons sou erf.

Hierdie historiese gegewenhede konfronteer ons ten slotte met 'n paar vrae:

1. Sien ons Calvyn nie veelal té oorspronklik, té afgesonder van die res van die Reformasie nie?

2. Is alles wat ons vandag Calvinisties noem inderdaad Calvinisties in dié sin dat dit sy oorsprong by Calvyn het? Is ons nie in ons opvattings baie keer histories onnoukeurig en onverantwoord nie?

3. Sou dit nie dien tot verbreding van perspektief en bevordering van die gepaste ootmoed indien ons ons opnuut gaan besin oor die invloed, nie alleen van Luther nie, maar ook van Bucer op die ontwikkeling van die jong Calvyn nie? Hiermee hang saam die vraag na die engheid of wydheid, die geslotenheid of openheid van die Calvinisme - 'n vraag wat in ons "ekumeniese" tyd nie sonder aktualiteit is nie.

Alberton.

L. F. Schulze.

1) Calvyn praat van die amp (ufficium) van die leraars (doktore). Daarom word van die kerkorde se terminologie van "dienste" afgewyk in die uiteensetting. Die onderskeiding tussen "dien" (functio) en amp (vgl. Handleiding by die Kerkorde, p. 47 en 50) le buite bestek van hierdie historiese skets.

2) Francois Wendel: Calvin, the origins and development of his religious thought, (Engelse vertaling van Philip Mairet), p. 75-76.

GERAADPLEEGDE_ WERKE

1. Joh. Jansen: Korte verklaring van die Kerkorde, Kok, Kampen, 3e druk, 1952. 
2. L. S. Kruger, H. L. M. du Plessis, B. Spoelstra en T. T. Spoelstra: Handleiding by die Kerkorde van die Geref. Kerk in Suid-Afrika, Pro Rege-Pers, Potchefstroom, 1966.

3. Fr. Wendel: Calvin, the origins and development of his religious thought (uit die Frans vertaal deur Philip Mairet) Collins, London, 1963.

4. G. Anrich: Straatsburg und die Calvinische Kirchenverfassung, Tü bingen, 1928. 